\title{
Rapid Sedimentation, Overpressure, and Focused Fluid Flow, Gulf of Mexico Continental Margin
} and the IODP Expedition 308 Scientists

\section{Abstract}

Expedition 308 of the Integrated Ocean Drilling Program (IODP) was the first phase of a two-component project dedicated to studying overpressure and fluid flow on the continental slope of the Gulf of Mexico. We examined how sedimentation, overpressure, fluid flow, and deformation are coupled in a passive margin setting and investigated how extremely rapid deposition of fine-grained mud might lead to a rapid build-up of pore pressure in excess of hydrostatic (overpressure), underconsolidation, and sedimentary mass wasting. Our tests within the Ursa region, where sediment accumulated rapidly in the late Pleistocene, included the first-ever in situ measurements of how physical properties, pressure, temperature, and pore fluid compositions vary within low-permeability mudstones that overlie a permeable, overpressured aquifer, and we documented severe overpressure in the mudstones overlying the aquifer. We also drilled and logged three references sites in the BrazosTrinity Basin IV and documented hydrostatic pressure conditions and normal consolidation. Post-expedition studies will address how the generation and timing of overpressure control slope stability, seafloor seeps, and large-scale crustal fluid flow. The operations of Expedition 308 provide a foundation for future long-term in situ monitoring experiments in the aquifer and bounding mudstones.

\section{Introduction}

Rapid sedimentation at rates $>1 \mathrm{~mm} \cdot \mathrm{yr}^{-1}$ generate overpressure in many sedimentary basins around the world (Rubey and Hubbert, 1959; Fertl, 1976). When low-permeability sediments are rapidly loaded, pore fluids cannot escape, and the fluids bear some of the overlying sediment load. In this situation a pore pressure exceeding the hydrostatic pressure (overpressure, $\mathrm{P}^{*}$ ) develops.
Recent work has focused on the coupling of rapid sedimentation and stratigraphic architecture to produce two- and three-dimensional flow fields. If, for example, permeable sand is rapidly buried by low-permeability mud of laterally varying thickness (Fig. 1), fluids flow sub-horizontally through the sand layer to regions of thin overburden before they are expelled into the overlying sediment. This creates characteristic distributions of sediment properties, fluid pressure, effective stress, temperature, and fluid chemistry in the aquifers and the bounding mud (Fig. 1). This simple flow-focusing process can cause slope instability near the seafloor (Dugan and Flemings, 2000; Flemings et al., 2002). In the deeper subsurface, overpressures created by focused flow can drive fluids through low-permeability strata to vent

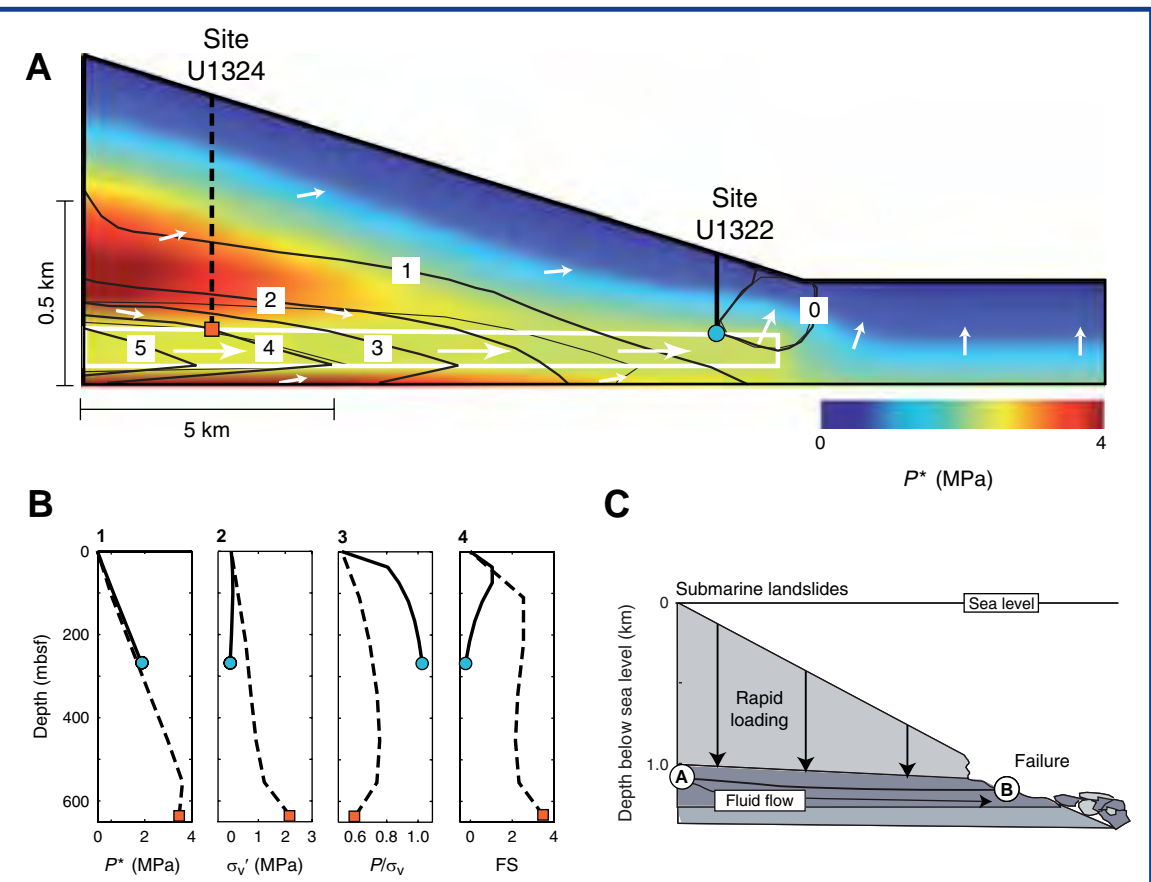

Figure 1. Flow-focusing model approximating conditions in Ursa Basin. [A] Low permeability sediments are rapidly deposited on a high permeability aquifer (outlined in white). Sedimentation rate decreases from left to right, resulting in final wedge-shaped geometry. Rapid sedimentation generates overpressure ( $\mathrm{P}^{*}$; color contours) that is greatest on the left (red) side of the picture. Flow is driven laterally (left to right) along the aquifer and is expelled at the toe of the slope where the aquifer ends (white arrows). Vertical effective stress (black contours) is lowest on the right side of the picture. [B] Predicted overpressure profiles where overburden is thick (Site U1324) and thin (Site U1322). (1) Overpressure at Site U1322 is slightly greater than at Site U1324 for equivalent depths. (2) Vertical effective stress ( $\sigma v^{\prime}$ ) is much lower at Site U1322 than at Site U1324. (3) Pore pressures (P) equal overburden stress (ov) at Site U1322. (4) Slope failure is predicted by infinite slope analysis near Site U1322 for FS $<1$. FS relates failure-driving stress to available shear strength for shallow failures. [C] Model parameters: low permeability mudstone $\mathrm{k}_{\mathrm{v}}<5 \times 10^{-8} \mathrm{~m}^{2}$ and $\mathrm{kh}^{2} 5 \times 10^{-16} \mathrm{~m}^{2}$; aquifer permeability $\mathrm{k}_{\mathrm{h}}=\mathrm{k}_{\mathrm{v}} 5 \times 10^{-14} \mathrm{~m}^{2}$; maximum sedimentation rate $=3.5 \mathrm{~mm} \cdot \mathrm{y}^{-1}$; minimum sedimentation rate $=0.8 \mathrm{~mm} \cdot \mathrm{y}^{-1}$. [C] Drawing of how flow focusing drives slope instability . 


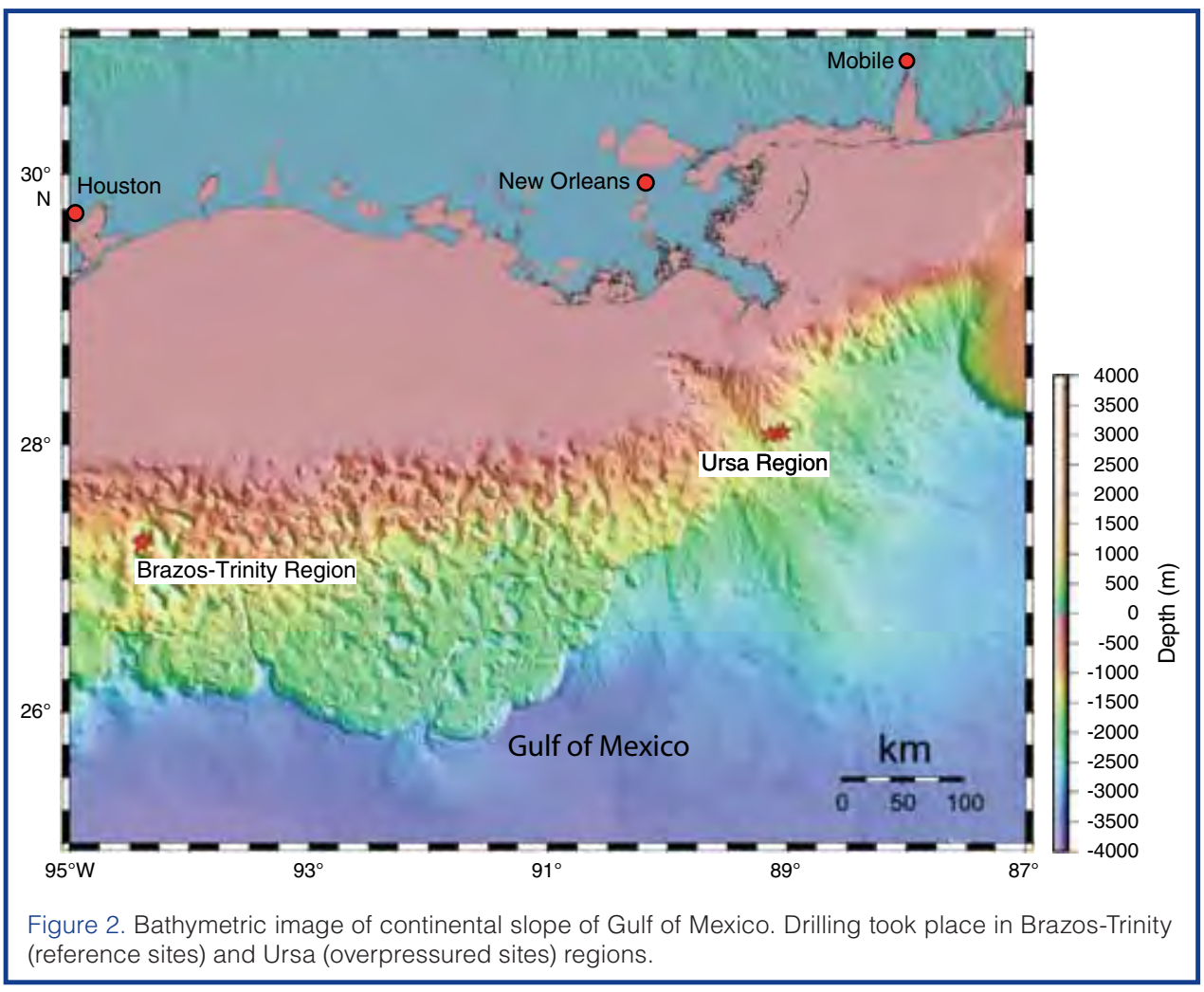

time in the history of scientific ocean drilling that a hole was drilled exclusively for logging purposes.

Integration of core, downhole measurement, and seismic data enabled a detailed lithostratigraphic (Fig. 4) and physicochemical characterization of the basin and dating of key surfaces. The data provide the basis to estimate sediment fluxes over time across a source-to-sink system. A 175-m-thick sequence of sand-rich turbidite fans, masstransport deposits, and hemipelagic sediment has accumulated within the last $\sim 120,000$ years in Brazos Trinity Basin IV. Pre-fan deposits form a conformable sequence dominated by terrigenous clays transported by dilute turbidity currents and river plumes. The two sequences are

ultimately at the seafloor (Boehm and Moore, 2002; Davies et al., 2002; Seldon and Flemings, 2005). This is a potentially important mechanism for the transfer of fluids from the solid earth to the hydrosphere and the atmosphere.

\section{Brazos-Trinity Reference Sites}

Brazos-Trinity Basin IV is located $200 \mathrm{~km}$ due south of Galveston, Texas (U.S.A.) in $\sim 1400 \mathrm{~m}$ of water (Fig. 2). As one of a chain of five basins that are separated by interbasinal highs, it is a classic area for analysis of turbidite depositional environments, and it is a modern analog to describe the formation of deep-water turbidite reservoir deposits (e.g., Badalini et al., 2000; Winker, 1996; Winker and Booth, 2000). The primary data used to evaluate the borehole locations comprise a high-resolution, twodimensional (2-D) seismic survey conducted by Shell Exploration and Production Company to image the turbidite stratigraphy. The three drilling sites are shown on dip seismic Line 3020 (Fig. 3). Site U1320 is located where the turbidite deposits are thickest, whereas Site U1319 lies along the southern flank of Basin IV where turbidite deposits are more condensed. Site U1321 was a loggingwhile-drilling and measurementwhile-drilling (LWD/MWD) site and was not cored. This is the first separated by a thin $(\sim 1 \mathrm{~m})$ layer of microfossil-rich clay, interpreted to represent the sea-level highstand during Marine Isotope Stage 5e. The basin infill is marked by two main pulses of mass-gravity flow deposition, separated by a pause in turbidity current activity. The pause lasted as much as $45 \mathrm{ky}$, starting at $\sim 90 \mathrm{ka}$. The microfossil-rich clays in this interval contain the Los Chocoyos ash layer (Y8), a physical correlation marker across Basin IV and adjacent basins. The lower part of the basin contains mostly thin-bedded, muddy turbidites. The upper part contains muddy slump deposits derived from the basin margin and sand-rich turbidites that form several packets of very fine to fine sand beds that are

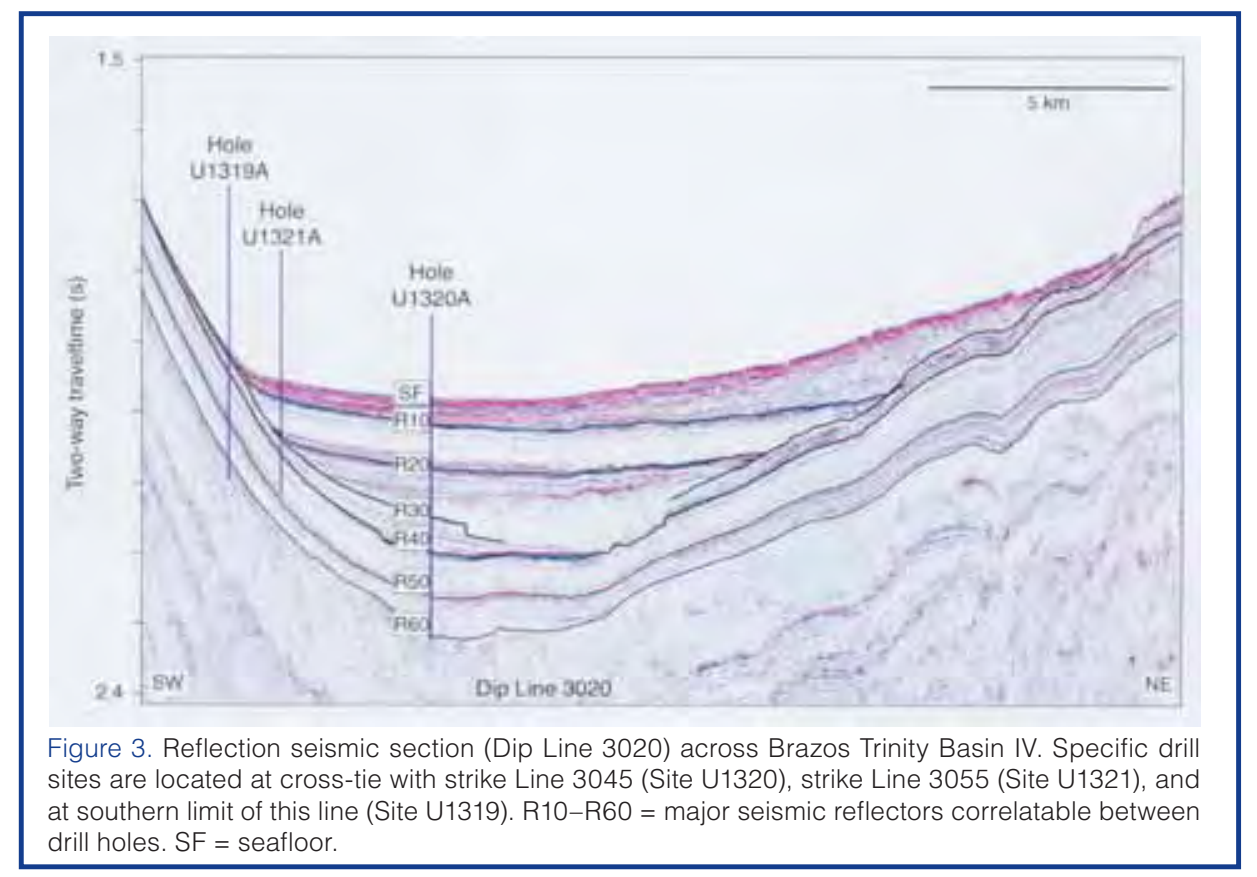




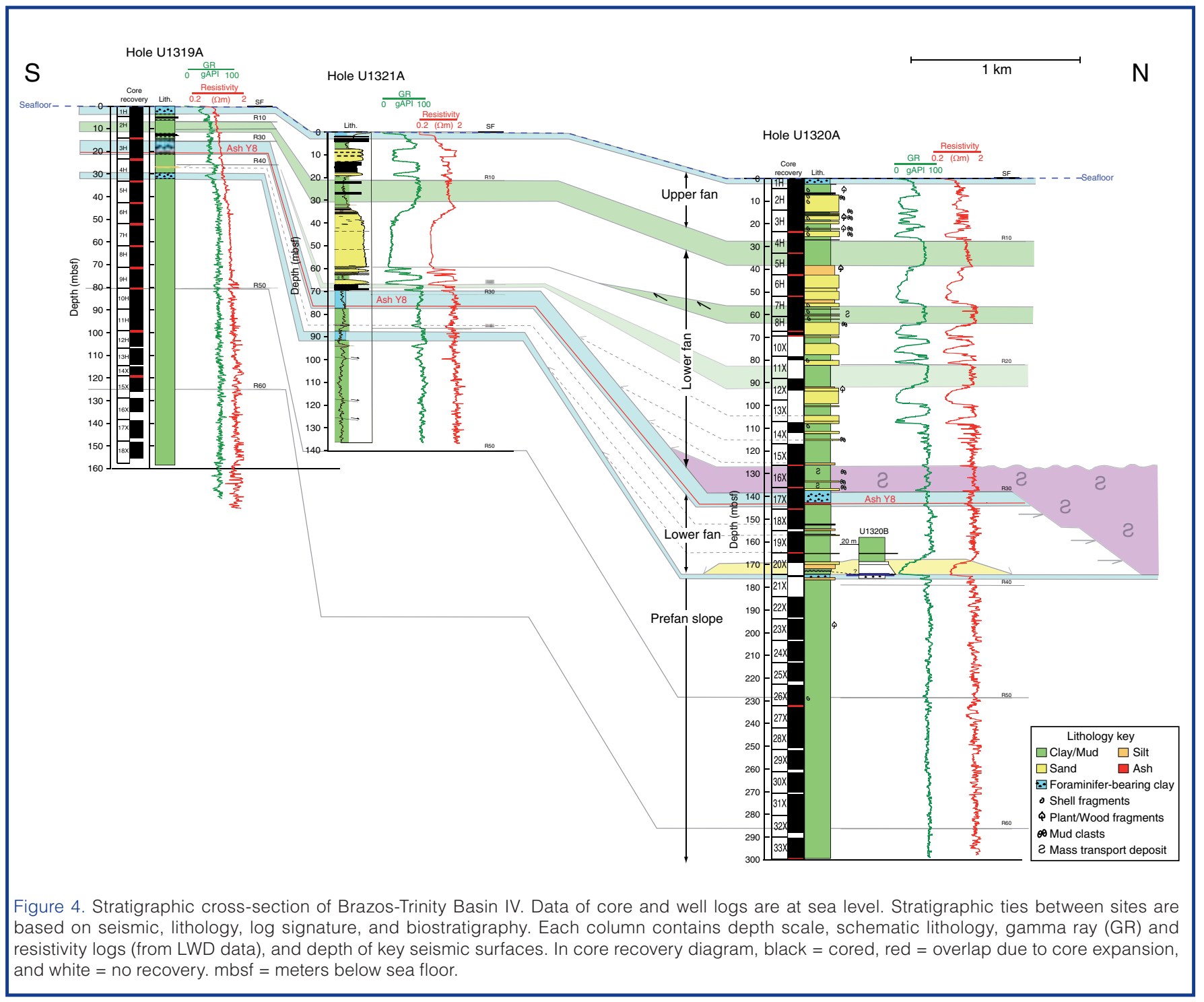

5-25 m thick (Fig. 4). Rates of basin subsidence, sea-level change, and average sediment accumulation or erosion are of similar magnitude in this system, resulting in a complex interaction between (a) sea level changes and deltaic dynamics, which affect the delivery of sediment in the source area, (b) salt tectonics, which affects the basin configuration and topographic gradients over time, and (c) the dynamic interaction between turbidity currents and the underlying topography.

The three drilling sites in the Brazos-Trinity Basin IV provided evidence of progressive and punctual downhole changes in physical properties as measured onboard the JOIDES Resolution, especially at Site U1319. Basin in-fill sediments (down to reflector R40) and underlying hemipelagic drape sediments (below reflector R40) are essentially non-slumped, normally consolidated muds that provide an excellent reference for materials found within the basin (Site U1320) and at Ursa Basin (Sites U1322 and U1324). The sediment porosity at Site U1319 decreases exponentially downhole from $80 \%$ to $50 \%$. In comparison, Site U1320 has a section of underconsolidated muds and clays below Reflector
R40; this was not anticipated but is explained by rapid sediment loading precluding fluid drainage and consolidation of muds of the basin interior.

\section{Overpressured Ursa Basin Sites}

Ursa Basin lies approximately $150 \mathrm{~km}$ south-southeast of New Orleans, Louisiana (U.S.A.) in $1000 \mathrm{~m}$ of water (Fig. 2). The region is of economic interest because of its prolific oilfields that lie $>4000$ meters below the seafloor (mbsf; e.g. Mahaffie, 1994). We were interested in the sediments from 0 to 1000 mbsf (e.g., Pratson and Ryan, 1994; Pulham, 1993). Four three-dimensional (3-D) seismic data sets were used to constrain stratigraphy within Ursa Basin. The highresolution surveys were conducted by Shell Exploration and Production Company for the purpose of shallow hazards analysis. Figure 5 shows the seismic transect along which Sites U1322, U1323, and U1324 were drilled. The sanddominated Mississippi Canyon Blue Unit (Fig. 5) is a latePleistocene "ponded fan" deposited in a broad topographic low. The Blue Unit is overlain by a mud-dominated leveechannel assemblage. The most spectacular feature is the 


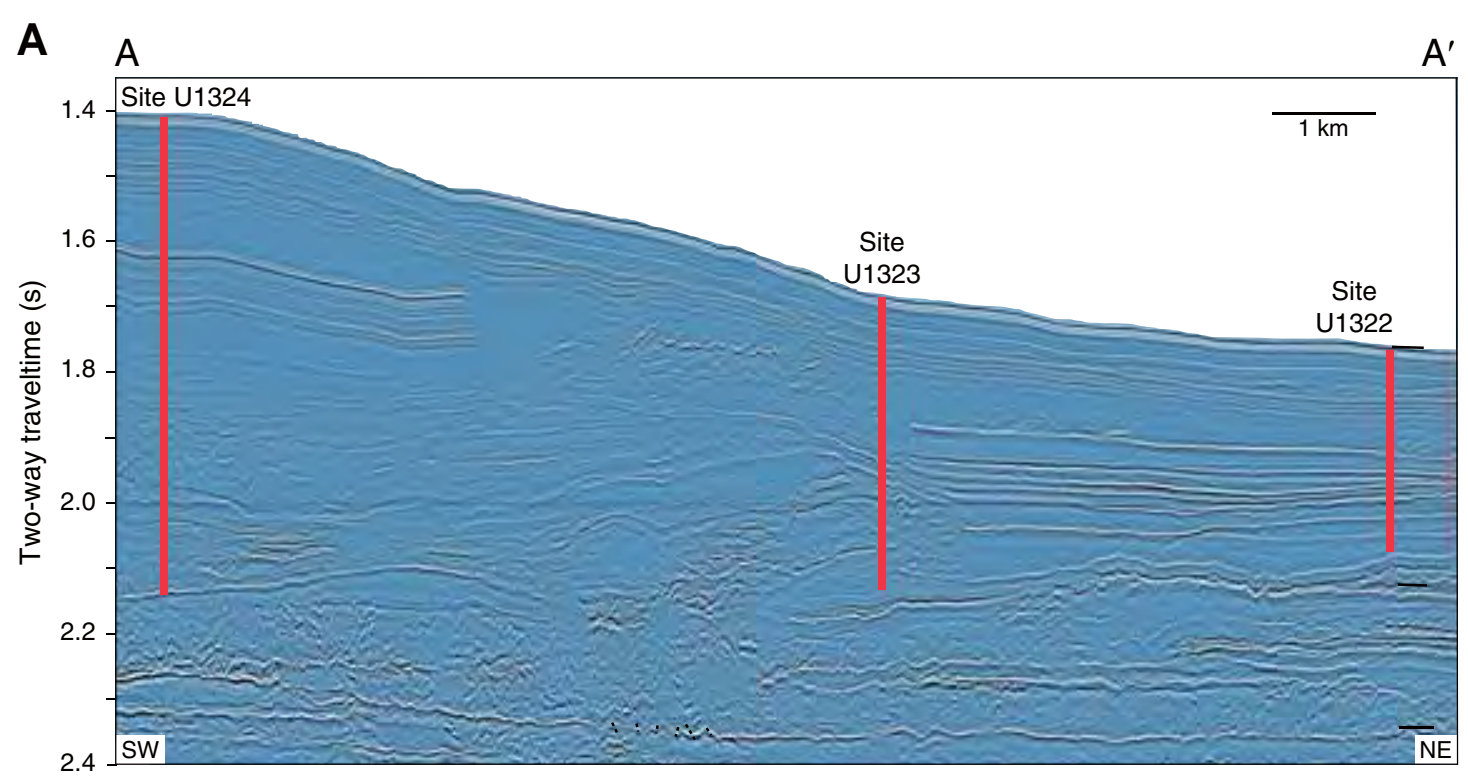

B

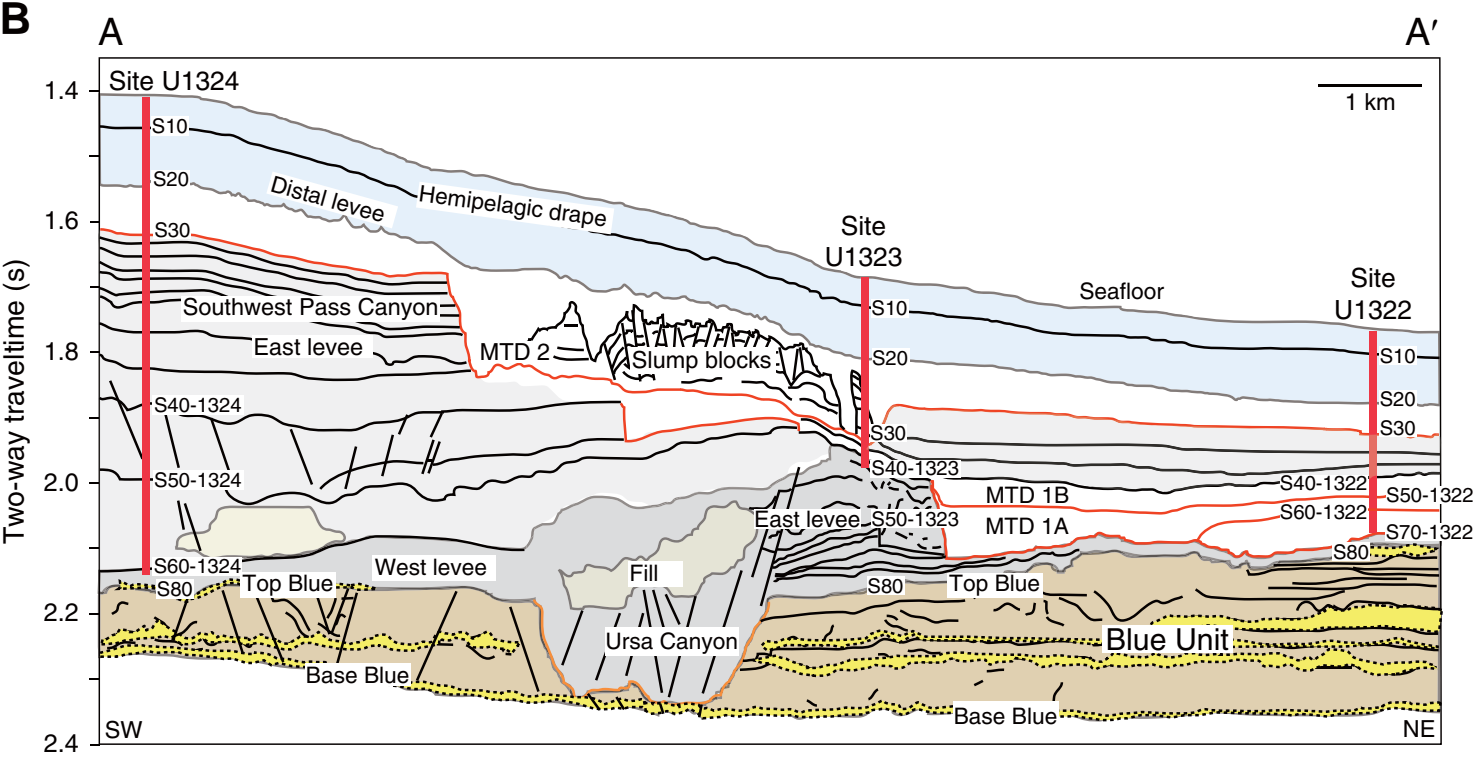

Figure 5. [A] Seismic cross-section A-A' from Ursa Basin. [B] Interpreted cross-section A-A'. Sand-prone Blue Unit has been incised by channel-levee complex and then overlain by thick and heavily slumped hemipelagic mudstone wedge that thickens westward (left). Blue Unit sands correlate to distinct seismic facies. Thickness of hemipelagic mudstone above Blue Unit does not change significantly in north-south direction. Seismic reproduced with permission of Shell Exploration and Production Company.

sand-cored levee-channel of the Ursa Canyon, overlain by the muddy eastern levee deposits of the Southwest Pass Canyon and a hemipelagic drape cover. The mudstone package lying above the Blue Unit has numerous detachment surfaces that record slumping and mass transport deposits.

The Ursa Basin sites provided a west-east transect that tested the flow-focusing model of differential loading on a permeable aquifer. Overburden was drilled and sampled to $608 \mathrm{~m}$ depth at Site U1324 (thick overburden) and to $234 \mathrm{~m}$ at Site U1322 (thin overburden). We used a penetrometer (Fig. 6) to measure overpressure below $100 \mathrm{~m}$ at both sites. Normalized overpressure of approximately 0.6 was determined at the base of each site (i.e., the pore pressure lies $60 \%$ of the way between hydrostatic pressure and lithostatic pressure). The temperature gradient is $18^{\circ} \mathrm{C} \cdot \mathrm{km}^{-1}$ at Site $\mathrm{U} 1324$ and $26^{\circ} \mathrm{C} \cdot \mathrm{km}^{-1}$ at Site U1322. Thermal conductivities at the two locations are similar $\left(1.15-1.2 \mathrm{~W} \cdot \mathrm{m}^{-1} \cdot \mathrm{K}^{-1}\right)$, implying a vertical conductive heat flow of $\sim 22 \mathrm{~mW} \cdot \mathrm{m}^{-2}$ at Site U1324 versus $\sim 30 \mathrm{~mW} \cdot \mathrm{m}^{-2}$ at Site U1322.

Sedimentation has accumulated more rapidly at Site $\mathrm{U} 1324\left(10 \mathrm{~mm} \cdot \mathrm{y}^{-1}\right)$ than at Site U1322 $\left(3.8 \mathrm{~mm} \cdot \mathrm{y}^{-1}\right)$. In spite of the almost three-fold difference in sedimentation rate, the similar overpressure gradients present at these two sites imply a component of lateral flow between them. This lateral flow drives fluids from Site U1324 toward Site U1322, increases the pressure at Site U1322 relative to a system with only vertical fluid migration, and decreases pressure at Site U1324 relative to a system with only vertical migration. The 
Blue Unit, composed of interbedded sheet sands and mudstones, is interpreted to facilitate the lateral transfer of fluids from Site U1324 to Site U1322, making the regional pressure field diverge from a simple one-dimensional, compaction system. Core, $\log$, and seismic interpretations document numerous scales of slumping, faulting, and softsediment deformation with increased occurrence at Site U1322. This deformation is consistent with predictions of the flow-focusing model. The dramatic difference in sedimentation rates between the sites also helps to explain the difference in observed thermal gradients. These results suggest that at the basin scale, this type of lateral fluid flow may be the prime factor for the distribution and occurrence of cold seeps, mud volcanoes, and repeated submarine landslides generating major mass transport deposits.

\section{Expectations and Achievements of IODP Expedition 308}

A fundamental achievement of IODP Expedition 308 is that the overpressure profile as a function of depth at Sites U1322 and U1324 in Ursa Basin could be directly measured. These measurements were difficult, and we experienced a high rate of failure; however, we ultimately acquired enough data to constrain the overpressure field above the Blue Unit. Preliminary interpretations suggest that flow focusing is occurring in this basin and contributing to deformation and failure of sediments where overburden is thin. This is the first time in the history of scientific ocean drilling that the spatial variation of the pressure field has been documented at such resolution. We also acquired an extraordinary data set documenting a striking difference in temperature gradients between Sites U1322 and U1324.

We wanted to establish reference logging and core properties where overpressure is not present at a range of effective stresses in Brazos-Trinity Basin IV. Coring and logging were successful at all locations there, resulting in a highresolution recontruction of basin architecture and lithostratigraphy, in part below the level of individual lithostratigraphic subunits.

Our data on pore pressure, sediment properties,

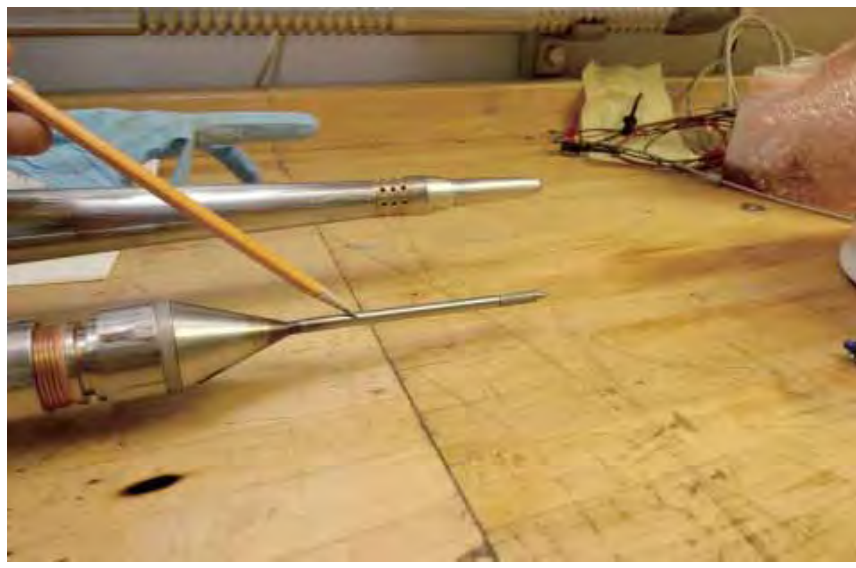

Figure 6. Temperature Two Pressure probe (T2P, foreground) and DavisVillinger Temperature-Pressure Probe (DVTPP, background). Both tools measure formation pressure by being forced into formation by drill string.

and overburden stress (Fig. 7) will provide a basis to assess the potential for slope failure, especially in Ursa Basin, and to estimate the conditions that drove previous slope failures. A major component of the ongoing post-expedition research is the integration of the stratigraphic geometry, physical properties, timing, and pressures associated with these mass-wasting processes.

IODP Expedition 308 monitored downhole pressure and lithology in real time using the MWD approach and for the first time used weighted mud as a tool to drill and core

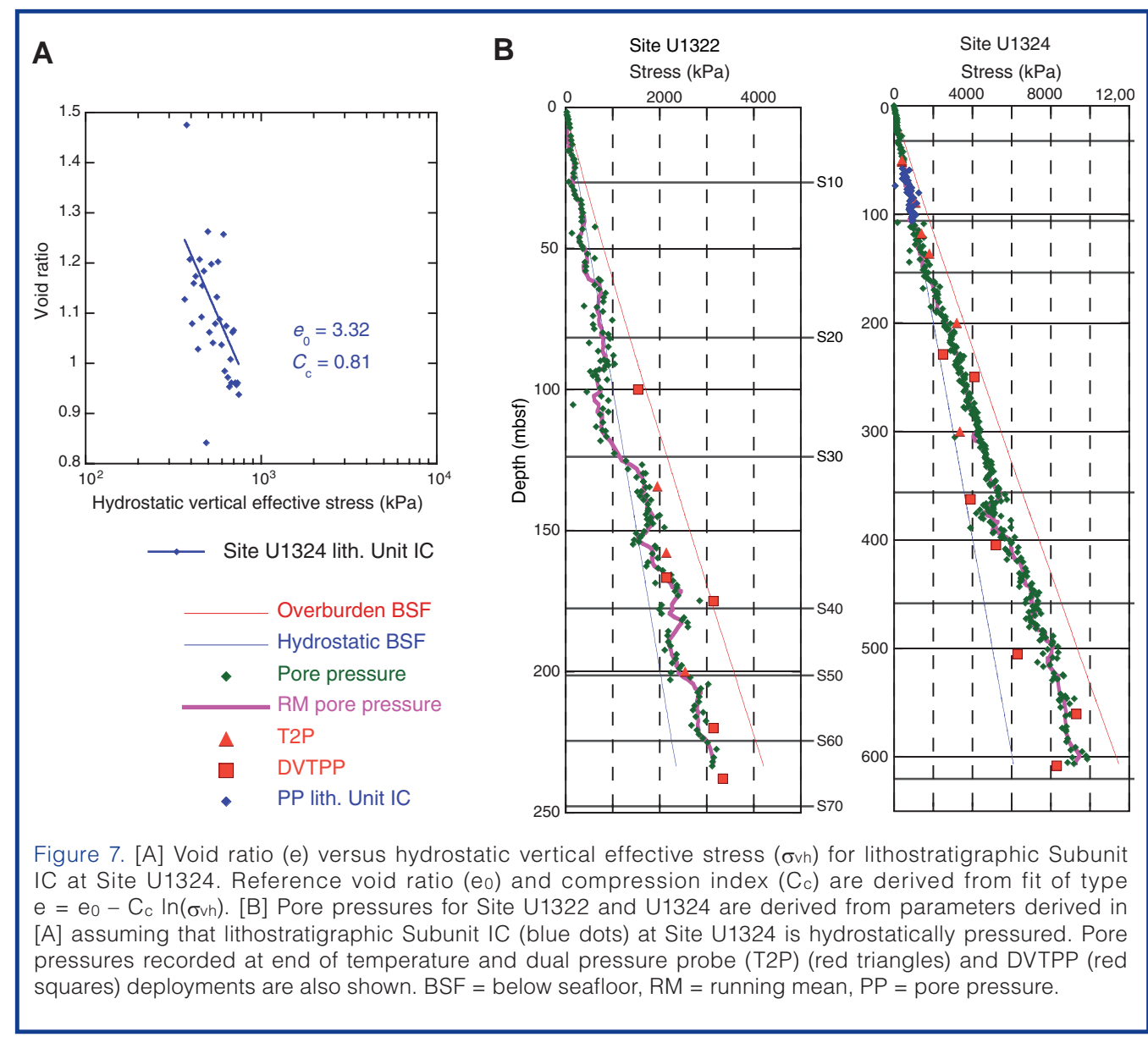


overpressured regimes. Real-time monitoring allowed us to observe shallow-water flow and to respond to this incident by raising the mud weight to retard flow into the borehole, thereby proving the feasibility of this technique for longterm, in situ monitoring experiments in the aquifer and bounding mudstones.

Data from the ponded turbidite system in Brazos Trinity Basin IV and the channelized systems present in Ursa Basin are of great interest for further studies by academic and industry researchers. They will likely break new ground, especially in the field of geotechnical and hydrogeological analysis of continental slopes along passive and active continental margins. We have also shown that in situ measurements of pore pressure in fine-grained sediments can be performed with overall success and that drilling into overpressured formations with riserless technology can be managed using heavy mud. Future drilling in a variety of settings might benefit from the controlled use of weighted mud to stabilize the borehole.

\section{Acknowledgements}

We are grateful for the assistance provided by the IODP technical and engineering groups and by the TRANSOCEAN marine and drilling staff aboard the JOIDES Resolution.

\section{IODP Expedition 308 Scientists}

J.H. Behrmann (Co-Chief Scientist), P.B. Flemings (CoChief Scientist), C.M. John (IODP Expedition Project Manager / Staff Scientist), G.J. Iturrino (logging staff scientist), Y. Aizawa, N.T.T. Binh, N. De Silva, B. Dugan, T. M. Edeskär, C. Franke, A. Gay, W.P. Gilhooly III, J. GutierrezPastor, S.Y. Jiang, H. Long, J.C. Moore, T. Nonoura, C. Pirmez, M. Reichow, D.E. Sawyer, J. Schneider, A.V. Shumnyk, T. Suzuki, Y. Takano, R. Urgeles, Y. Yamamoto and V. Zampetti.

\section{References}

Badalini, G., Kneller, B., and Winker, C.D., 2000. Architecture and processes in the late Pleistocene Brazos-Trinity turbidite system, Gulf of Mexico continental slope. Deep-Water Reservoirs of the World: Proc. GCSSEPM 20th Annu. Res. Conf., pp.16-34.

Boehm, A., and Moore, J.C., 2002. Fluidized sandstone intrusions as an indicator of paleostress orientation, Santa Cruz, California. Geofluids, 2(2):147-161, doi:10.1046/j.14688123.2002.00026.x.

Davies, R., Bell, B.R., Cartwright, J.A., and Shoulders, S., 2002. Three-dimensional seismic imaging of Paleogene dike-fed submarine volcanoes from the northeast Atlantic margin. Geology, 30:223-226.

Dugan, B., and Flemings, P.B., 2000. Overpressure and fluid flow in the New Jersey Continental Slope: implications for slope failure and cold seeps. Science, 289:288-291, doi:10.1126/ science.289.5477.288.

Fertl, W.H., 1976. Abnormal Formation Pressures: Implications to Exploration, Drilling, and Production of Oil and Gas Resources: Amsterdam (Elsevier).

Flemings, P.B., Stump, B.B., Finkbeiner, T., and Zoback, M., 2002. Flow focusing in overpressured sandstones: theory, observations, and applications. Am. J. Sci., 302:827-855, doi:10.2475/ajs.302.10.827.

Mahaffie, M.J., 1994. Reservoir classification for turbidite intervals at the Mars discovery, Mississippi Canyon Block 807, Gulf of Mexico. In Bouma, A.H., and Perkins, B.G. (Eds.), Submarine Fans and Turbidite Systems: Proc. GCSSEPM 15th Annu. Res. Conf., pp.233-244.

Pratson, L.F., and Ryan, W.B.F., 1994. Pliocene to recent infilling and subsidence of intraslope basins offshore Louisiana. $A A P G$ Bull., 78:1483-1506.

Pulham, A.J., 1993. Variations in slope deposition, PliocenePleistocene, offshore Louisiana, northeast Gulf of Mexico. In Posamentier, H., and Weimer, P. (Eds.), Siliclastic Sequence Stratigraphy: Recent Developments and Applications. AAPG Mem., 58:199-233.

Rubey, W.W., and Hubbert, M.K., 1959. Role of fluid pressure in mechanics of overthrust faulting, Part 2. Overthrust belt in geosynclinal area of western Wyoming in light of fluid-pressure hypothesis. Geol. Soc. Am. Bull., 70:167-205.

Seldon, B., and Flemings, P.B., 2005. Reservoir pressure and seafloor venting: Predicting trap integrity in a deepwater turbidite reservoir. AAPG Bull., 89(2): 193-209, doi:10.1306/09170403122.

Winker, C.D., 1996. High-resolution seismic stratigraphy of a late Pleistocene submarine fan ponded by salt-withdrawal minibasins on the Gulf of Mexico continental slope. Proc. 3rd Annu. Offshore Technol. Conf., 28(1):619-628.

Winker, C.D., and Booth, J.R., 2000. Sedimentary dynamics of the salt-dominated continental slope, Gulf of Mexico: integration of observations from the seafloor, near-surface, and deep subsurface. Deep-Water Reservoirs of the World: Proc. GCSSEPM 20th Annu. Res. Conf., pp.1059-1086.

\section{Authors}

Jan H. Behrmann, IFM-GEOMAR, Wischhofstr. 1-3, 24148 Kiel, Germany e-mail: jbehrmann@ifm-geomar.de

Peter B. Flemings, Department of Geosciences, Pennsylvania State University, 307 Deike Building, University Park, Pa. 16802-2714, U.S.A.

Cédric M. John, Integrated Ocean Drilling Program, 1000 Discovery Drive, College Station, Texas 77845, U.S.A.

and the IODP Expedition 308 Scientists

\section{Related Web Link}

http://iodp.tamu.edu/scienceops/expeditions/exp308.html 